\title{
THE IMPORTANCE OF SOCIAL CAPITAL FOR FAITH-BASED ORGANIZATIONS IN THE NEW NORMAL ADAPTATION OF WEST SUMATERA
}

\author{
Inda Mustika Permata ${ }^{1 *}$, Bima Jon Nanda ${ }^{2}$, Rifki Dermawan ${ }^{3}$ \\ ${ }^{1}$ Department of International Relations, Andalas University, Indonesia, email: indamustikapermata@soc.unand.ac.id; \\ ${ }^{2}$ Department of International Relations, Andalas University, Indonesia, email:bimajonnanda@soc.unand.ac.id; \\ ${ }^{3}$ Department of International Relations, Andalas University, Indonesia, email:rifkidermawan@soc.unand.ac.id \\ *Correspomding Author
}$$
\text { cc) (1) (2) }
$$
(C)2021 by the authors. Submitted for possible open access publication under the terms and conditions of the Creative Commons Attribution-ShareAlike 4.0 International License-(CC-BY-SA) (https://creativecommons.org/licenses/by-sa/4.0/) doi DOI : http:/ / dx.doi.org/10.30983/islam_realitas. v7i1.3728
\begin{tabular}{|l|l|l} 
Submission: 23 November 2020 & Revised: 22 July 2021 & Published: 31 July 2021
\end{tabular}

\begin{abstract}
This paper seeks to explain the importance of faith-based organizations as social capital during the new normal era in West Sumatra. Considering West Sumatra is identical with the strong Islamic Identity and the increase of Covid-19 cases which put the region in the 6th highest number in Indonesia, this research is imperative to be conducted. Referring to WHO's policy, the local government of West Sumatra has imposed several regulations for new normal adaption and controlling the Covid-19 in the society. Therefore, this paper uses qualitative methods and social capital is applied for interpreting data. The data used in this study is the primary and secondary data - the primary data. We argues that the religious character of West Sumatra society provides opportunities for faith-based organizations to support the government in reducing the number of positive cases by educating people through Ulama who actively play a role in daily life.
\end{abstract}

Keywords: Covid-19, Social Capital, West Sumatra, New Normal

\section{Abstrak}

Tulisan ini berupaya untuk. menjelaskan mengenai pentingnya organisasi berbasis agama sebagai modal sosial pada masa new normal di Sumatera Barat. Sumatera Barat identike dengan identitas Islam yang kuat. Peningkatan kasus Covid-19 menempatkan Sumatera Barat pada urutan ke-6 di Indonesia. Maka dari itu penelitian ini menjadi penting untuk dilakukan. Mengacu pada kebijakan WHO, Pemerintah Daerah Sumatera Barat telah memberlakukan peraturan tentang adaptasi new normal dan pengendalian Covid-19 di masyarakat. Tulisan ini menggunakan metode kualitatif dan modal sosial digunakan untuk. menginterpretasikan data. Jenis data primer dan data sekunder digunakan dalam tulisan ini. Kami berpendapat bahwa karakter masyarakat Sumatera Barat yang agamais memberikan peluang bagi organisasi berbasis agama dalam mendukung pemerintah menekan jumlah kasus positif dengan mendidik masyarakat lewat ulama yang aktif berperan dalam kehidupan sehari-bari.

Kata Kunci: Covid-19, Modal Sosial, Sumatera Barat, New Normal

\section{Background}

Covid-19 is a global health problem that has spread throughout the world from areas in China, Wuhan. Indonesia is the highest country in ASEAN in terms of the number of positive cases of Covid-19. ${ }^{1}$ Meanwhile, West Sumatra is the province with the 6th highest number of Covid-19 cases in Indonesia, which is 15,013 cases, on November 3, 2020. ${ }^{2}$ The number of cases indicates the lack of good

\footnotetext{
${ }^{1}$ Dezan Shira and Associates, 'The Coronavirus in Asia and ASEAN - Live Updates by Country', ASEAN Briefing

$<$ https://www.aseanbriefing.com/news/coronavirus-
}

asia-asean-live-updates-by-country $>$ [accessed 23 November 2020].

2 'Peta Sebaran 8 November 2020' <https://covid19.go.id/peta-sebaran> [accessed 8 November 2020]. 
implementation of new normal in West Sumatra, which has been implemented since June $8,2020 .^{3}$

In addition to implementing regulation of New Normal Adaptation in Virus Prevention and Control No.6 of 2020, it is also necessary to observe the character of the people of West Sumatra to maximize the application of new normal. West Sumatra is inhabited by a majority Muslim population and has a strong Islamic identity. ${ }^{4}$ This identity is reflected in the life philosophy of the Minangkabau people, namely the adat basandi syara', syara' basandi Kitabullah. This philosophy means that adat is based on Sharia, Sharia is based on the Koran. Therefore, the religious character of West Sumatra society will make it easier for faithbased organizations, particularly Islam, to assist the West Sumatra government in implementing new normal. This opportunity is seen from the role of faith-based organizations in several countries in helping to address health problems, such as in Tanzania, ${ }^{5}$ West African countries (Guinea, Liberia, Sierra Leone), ${ }^{6}$ Eastern Europe (Russia, Romania, and Armenia) ${ }^{7}$. Referring to this, a discussion of the role of faith-based organizations is more focused on the African and Eastern European regions.
Furthermore, Hepworth and Stitt emphasized that faith-based organizations have a significant role in the 21st century. They also argue that religious groups are the leading formers of social capital in local communities, especially in the education sector, charities, and services to needy citizens, and has been considered a political force. ${ }^{8}$ Then, Farooqi argues that social capital in Islam is a network that helps to create relationships which then motivates people to follow habits or norms. ${ }^{9}$ It shows that a faithbased organization can contribute to society. Francis Fukuyama, in his writing, Social Capital and Civil Society, explains that social capital is a reciprocal informal norm that promotes cooperation between two or more individuals. Therefore, trust, networks and civil society are always associated with social capital because social capital cannot just be formed. ${ }^{10}$ Then, Bunn and Wood relate that faith-based organizations consider as one of the generators of social capital in contemporary society. ${ }^{11}$ It is crucial because social capital can facilitate cooperation between actors in different spaces. In this case, faith-based organizations can be categorized as bridging social capital. Putnam also adds that religious communities are an
3 Lilis Khalisotussurur and Andri Mardiansyah, 'Hari Ini Sumbar Resmi Terapkan New Normal', VivaNews, 2020

<https://www.viva.co.id/berita/nasional/1278556-

hari-ini-sumbar-resmi-terapkan-new-normal> [accessed 18 November 2020].

4 Delmus Puneri Salim and Lies Kryati, 'Politik Pendidikan Agama dan Perubahan Prilaku di Sumatera Barat', El-Hekam, $2.1 \quad$ (2018), 51 $<$ https://doi.org/10.31958/jeh.v2i1.825>.

${ }^{5}$ Eudora Chikwendu, 'Faith-Based Organizations in Anti-HIV/AIDS Work Among African Youth and Women', Dialectical Anthropology, 28.3-4 (2004), 324 <https://doi.org/10.1007/s10624-004-3589-1>.

6 Allen G.P. Ross, Remigio M. Olveda, and Li Yuesheng, 'Are We Ready for a Global Pandemic of Ebola Virus?', International Journal of Infectious Diseases, 28 (2014), 218

<https://doi.org/10.1016/j.ijid.2014.09.001>.
${ }^{7}$ Elisabet le Roux, 'Faith-Based HIV Response in Post-Soviet Eastern Europe: The Case of Channels of Hope in Russia, Romania, and Armenia', Development in Practice, $\quad 27.5 \quad$ (2017), 658-69 <https://doi.org/10.1080/09614524.2017.1327022>.

${ }^{8}$ Christine Hepworth and Sean Stitt, 'Social Capital \& Faith-Based Organisations', The Heythrop Journal, 48.6 (2007), 895-96 <https://doi.org/10.1111/j.14682265.2007.00348.x >.

9 Abul Hassan Farooqi, 'Islamic Social Capital and Networking', Humanomics, $22.2 \quad$ (2006), 115 <https://doi.org/https://doi.org/10.1108/08288660 610669400>.

10 Francis Fukuyama, 'Social Capital and Civil Society', IMF Working Papers, 00.74 (2000), 3 <https://doi.org/10.5089/9781451849585.001>.

${ }^{11}$ Christopher Bunn and Matthew Wood, 'Cultured Responses: The Production of Social Capital in Faith Based Organizations', Current Sociology, 60.5 (2012), 636 <https://doi.org/10.1177/0011392111425598>. 
essential source of social capital. Because religion can encourage the voluntary participation of formal groups, especially related to health problems. From the writings above, it shows that many experts have discussed about social capital and faith-based organization, but no one has discussed how it relates to adaptation of new normal. Therefore, this paper focuses more on discussing the contribution of social capital in West Sumatera in the case of new normal adaptation.

This paper applied a qualitative method. The data used in this study is the primary and secondary data- the primary data collected through interviews with representatives of the Muhammadiyah and Nahdlatul Ulama in West Sumatra. Meanwhile, secondary data obtained from journal articles, books, reports, and news based on keywords such as new normal, West Sumatra, Covid-19, Muhammadiyah, Nahdlatul Ulama, Faith-based organizations. After the data was collected, data triangulation was then carried out, namely by comparing the data obtained from interviews, report documents, books, and journal articles used. The data is then analyzed using a conceptual framework, namely, social capital, which aims to explain the efforts of faith-based organizations in West Sumatra in helping the government maximize the adaptation of new normal in society. In the beginning, this paper discusses who the faith-based organizations in West Sumatra are and their contribution to the society. Furthermore, it explains the challenges in West Sumatra toward the new normal adaptation process. Finally, it explains the importance of a faith-based organization in
West Sumatra in the new normal adaptation process

\section{Contribution of Faith-Based Organization to the Society}

West Sumatra is one of the provinces in Indonesia which has a very dominant number of Muslim communities. Based on data from the Central Statistics Agency in 2020, Islam is the religion practised by the majority of West Sumatra residents. Some $98.02 \%$ of the total population of West Sumatra are Muslim community groups. ${ }^{12}$ So, it is very natural that Islam has a central role in everyday life in the province of West Sumatra. Various facts show how Islam has an essential function for the West Sumatra public. One of them is the philosophy that is guided by the Minangkabau community, namely "the custom of basandi syarak, syarak basandi Kitabullab" or commonly abbreviated as ABS-SBK. The first phrase of this sacred sentence means that the Minangkabau custom, which is a culture in West Sumatra is based on religion which here refers to Islam. At the same time, the second phrase means religion based on Koran. This philosophy has a significant influence on the foundation of policymaking in the province of West Sumatra. ${ }^{13}$ Zainal also emphasizes that the ABS-SBK principle is a reflection of the lives of West Sumatra residents who are obedient in living their lives as Muslims. ${ }^{14}$ Another evidence shows the role of Islam is the placement of the figure of the ulama as an important figure among the population of West Sumatra. Ulama are actively involved in various social activities. For example, in the 2019 general election in the city of Padang Panjang, the General Election Commission

\footnotetext{
Filsafat, $\quad 17.1 \quad$ (2020), $\quad 9-13$

<https://doi.org/10.22515/ajpif.v17i1.2289>.

${ }^{14}$ Zainal, 'Gerakan Islamis di Sumatera Barat Pasca Orde Baru', MIQOT: Jurnal Ilmu-Ilmu Keislaman, 38.2 (2014), 462

<https://doi.org/10.30821/miqot.v38i2.103>.
} 
instituted communication with ulama to socialize the election. ${ }^{15}$

The strong connection between the people of West Sumatra and Islam has encouraged the formation of various faithbased organizations based on Islamic religious values. According to Clarke and Jennings, faith-based organizations are organizations that base their activities on the teachings and principles of beliefs they believe. ${ }^{16}$ Referring to data from the Ministry of Religion of West Sumatra Province (2016), there are 30 Islamic organizations located in West Sumatra. ${ }^{17}$ From the aspect of membership, these institutions are quite diverse. They are starting from community groups in general, the da'wa movement, to organizations with Muslim students and students as members. Some of these organizations are representatives of central institutions stationed in regions, such as the Regional Leadership of the West Sumatra Province Nahdlatul Ulama (PW NU), West Sumatra Aisyiyah Regional Leaders, the Regional Management Board of the Indonesian Mosque Youth Youth Communication Agency (DPW BKPRMI) and other groups.

From a historical review, West Sumatra has dominated the development of Islamic organizations in Indonesia. One of the largest in Indonesia is Muhammadiyah. This organization initially appeared in the Java area and then began to develop in West Sumatra. From the West Sumatra region, Muhammadiyah managed to expand to most of Sumatra, and other large islands such as Sulawesi and Kalimantan. ${ }^{18}$ According to Rohman and Mulyati (2019), the history of Muhammadiyah shows that West Sumatra has played a role in Muhammadiyah's success. Even for West Sumatra, Muhammadiyah has made a significant contribution, especially in the field of education. The education scheme and curriculum and administration system are changes carried out by Muhammadiyah so that Islamic education in West Sumatra is transformed from traditional procedures to be more modern. ${ }^{19} \quad$ Muhammadiyah's contribution also shows that through education, Islamic values can be internalized from an early age of the children.

Also, Muhammadiyah has a division related to disaster affairs, namely the Muhammadiyah Disaster Management Center (MDMC). ${ }^{20}$ The function of this division is to manage the disaster preparation process. This division also has a structure from the centre to the region. ${ }^{21}$ Muhammadiyah is the secondlargest Islamic organization in Indonesia has become the most active organization in responding to disasters in Indonesia, such as the Yogyakarta earthquake in 2006, the West Sumatra earthquake in 2009, and the eruption of Mount Merapi in 2010. ${ }^{22}$ Muhammadiyah's

18 Marpuah, 'Dinamika Muhammadiyah Sebagai Gerakan Pembaruan di Provinsi Sumatera Barat', Penamas, 33.1 (2020), p. 115.

19 Fandy Aprianto Rohman and Mulyati, 'Rintisan Awal Pendidikan Muhammadiyah di Sumatra Barat Tahun 1925-1939', Jurnal Penelitian Sejarah dan Budaya, 5.1 (2019), 26.

20 Muhammadiyah Disaster Management Center, 'Visi dan Misi' <https://www.mdmc.or.id/profilmdmc/visi-dan-misi> [accessed 18 November 2020].

21 Yusuf Adam Hilman, 'Disaster Management Concept of Muhammadiyah Disaster Management Centre in Ponorogo, Indonesia', Otoritas: Jurnal Imu Pemerintahan, $8.1 \quad$ (2018), <https://doi.org/10.26618/ojip.v8i1.807>.

22 Robin Bush, 'Muhammadiyah and Disaster Response: Innovation and Change in Humanitarian 
role in disaster management in West Sumatra is such as sending volunteers for search and rescue activities. These volunteers are mobilized and coordinated by Muhammadiyah, especially when responding to the earthquake in West Sumatra in 2009. ${ }^{23}$ MDMC then carried out a post-disaster rehabilitation program organized by Muhammadiyah. $^{24}$

Besides Muhammadiyah, Nahdlatul Ulama is also one of the largest Islamic organizations in Indonesia which also has disaster management that will respond quickly if a disaster occurs in Indonesia, known as the Community Based Disaster Risk Management Nahdlatul Ulama (CBDRMNU). This division collaborated with AusAID to provide assistance equivalent to AUD 250,000 during the earthquake in West Sumatra in 2009, targeted assistance received by 10,000 people and reached 24 remote villages in West Sumatra. Nahdlatul Ulama through CBDRMNU sent volunteers to West Sumatra to provide health assistance, school equipment, clothing and sanitation. Nahdlatul Ulama also mobilized local leaders, volunteers and ulama in West Sumatra to help earthquake victims (The Jakarta Post, 2009). ${ }^{25}$

Both Muhammadiyah and Nahdlatul Ulama do not only focus on spreading religion, but also contribute to solving problems that occur, such as earthquakes. The community response to the involvement of faith-based organizations during the earthquake was very positive. They feel they can deal with earthquake disasters because of the religious community around them. ${ }^{26}$ It shows that there is public trust in faith-based organizations that are present in every line of life, especially in West Sumatra. Their existence also shows that the organization is an important actor capable of assisting the government in increasing progress.

\section{The Challenges of New Normal Adaptation in West Sumatra}

After the three stages of implementing the Large-Scale Social Restriction, the Government officially adopted the new normal procedure in West Sumatra. New normal is a guideline for living life amid the spreading of the Covid-19 pandemic. Until now, all countries in the world are working to find a vaccine and cure for the Covid-19 virus. Through this new normal, according to Dr. Tedros, WHO Director-General, hopes that all countries can have the same standards in dealing with the Covid-19 problem. Indonesia is currently actively implementing 3T, namely Testing, Tracing, and Treatment. ${ }^{27}$ These three steps are a standard form of tackling Covid-19 in Indonesia. Therefore, all provinces in Indonesia must adapt to this step.

Besides, West Sumatra is trying to adopt a strategy to minimize the transmission of Covid-19 as instructed by the WHO. The strategies are grouped into four categories, namely for personal action, action in groups, prevention of transmission from high infection areas, and finally measures for

/ nu-ausaid-extend-aid-quake-victims.html> [accessed 18 November 2020].

${ }^{26}$ Gianisa Adisaputri, 'The Role of Religious Beliefs and Practices in Disaster: The Case Study of 2009 Earthquake in Padang City, Indonesia' (Auckland University of Technology, 2016) <https://core.ac.uk/download/pdf/80334097.pdf>.

${ }^{27}$ Sekretariat Kabinet RI, 'Rapat Terbatas Mengenai Percepatan Penanganan Pandemi Covid-19' $<$ https://setkab.go.id/rapat-terbatas-mengenaipercepatan-penanganan-pandemi-covid-19-13-juli2020-di-istana-merdeka-provinsi-dki-jakarta/> [accessed 18 November 2020]. 
vulnerable groups and medical personnel. In order to maximize the adaptation to the new normal, the government has passed local regulations regarding the obligation to comply with health protocols. This regulation aims to provide binding legality of the new norms being applied. However, in reality, the number of positive cases in West Sumatra is still increasing. On November 3, West Sumatra was ranked 6th in Indonesia. Besides, the number of positive cases increased after this rule was passed. Referring to the West Sumatra Corona site, on September 11, 2020, when this rule was passed, the number of positive cases was 1286 people. Then on November 3, 2020, the positive cases increased to 3622 cases. $^{28}$ This data shows that even though the rules have been implemented, positive cases of Covid-19 still cannot be suppressed.

The high number of Covid-19 in West Sumatra is undoubtedly a challenge for the West Sumatra Government. When parsed again, the reasons for this number are still increasing; namely, first, there is a public perception that Covid-19 is not a danger. Quoting the results of a survey conducted by Suara Komunitas, people assume that the pandemic will end in June 2020. ${ }^{29}$ The number of Covid-19 cases is still increasing until November. Then, from the results of the PMI survey, after the new normal was implemented, the public felt that Covid-19 was no longer as threatening as before. ${ }^{30}$ This kind of perception will undoubtedly trigger an increase in Covid-19 transmission. In addition, the sense of not being threatened is also caused by the fact that people do not understand the meaning of the word "new normal". It is evident from the results of the PMI Survey that only $22 \%$ of respondents answered correctly about the meaning of the word "new normal". ${ }^{31}$

Furthermore, the second is community behaviour related to the covid-19 virus. The implication of the public's perception that after the new normal is implemented, the situation has returned to what it was before the pandemic would undoubtedly trigger an increase in positive cases. People have become ignorant of health protocols. From a survey conducted by the Central Statistics Agency (BPS), $55 \%$ of respondents thought that the absence of severe sanctions was the cause of the ineffective health protocol. ${ }^{32}$ This data is of concern because $20.56 \%$ of respondents leave the house more often than before the implementation of the new normal. ${ }^{33}$ This means that this condition will encourage people to gather somewhere. Still quoting from BPS, the following is the list of places most at risk of transmission of the virus due to the absence of application of health protocols, namely, traditional markets, places of worship, workplaces, shopping places/malls, and finally public services. ${ }^{34}$ Based on these data, it is challenging to restrict human movement to break the chain of viruses. It is undoubtedly a challenge for the government.

Besides, people object to check, because of the high price and the result come too long. A factor other than cost is the existence of a negative stigma that appears in society towards patients or survivors. Referring to the LaporCovid19 survey, $55 \%$ of respondents admitted to being a topic of conversation in the community, then $33 \%$ were ostracized, and

\footnotetext{
28 Sumbar Tanggap Corona, 'Data Pantauan 3 November 2020 '

$<$ https://corona.sumbarprov.go.id/details/index_mas ter_corona $>$ [accessed 18 November 2020].

29 Aulia Arriani and et al, 'The Community's Perception of Covid-19', Suara Komunitas, August 2020, p. 10.

30 Arriani and et al.
}

\footnotetext{
31 Arriani and et al.

32 Badan Pusat Statistik, 'Perilaku Masyarakat Di

Masa Pandemi Covid-19', p. 17

<https://covid19.go.id/edukasi/hasil-kajian/hasilsurvei-perilaku-masyarakat-di-masa-pandemi-covid19> [accessed 18 November 2020].

${ }^{33}$ Badan Pusat Statistik.

${ }^{34}$ Badan Pusat Statistik.
} 
$24 \%$ got the nickname as spreaders or carriers of the virus. ${ }^{35}$ The survey results illustrate that there is no understanding of the importance of virus prevention and control in the community. This survey also shows that the government needs to correct rumors and hoaxes related to Covid-19 in the community. Currently, the government is also conducting clinical trials related to the Covid-19 virus vaccine. After the clinical trial is complete, the national government will conduct the vaccination. From the results of the LaporCovid-19 survey, 65\% of the people of West Sumatra know about the government's plan. Regarding the level of willingness to be Because from the survey, only $47 \%$ of respondents were willing. ${ }^{36}$ In the study, the factors that caused the low willingness to be vaccinated were concerns about the safety and effectiveness of the vaccines, distrust of vaccines, and the halal issue of vaccines. ${ }^{37}$ This assumption certainly cannot be ignored because it can exacerbate the conditions for broader virus transmission.

\section{The Importance of the Faith-Based Organizations in New Normal}

In facing a disaster, religion is essential to guide society's behaviour to be more patient and resilient. According to Gaillard and Texier, faith-based organizations then play a role in reducing the risk of a disaster. Religious groups vaccinated, West Sumatra is relatively low.

are usually better integrated into local communities and can usually respond to a disaster in a short and short time. ${ }^{38}$ Based on the writings of Gillard and Paton, religion is considered one of the things that make people face a disaster. ${ }^{39}$ Faith-based organizations speak the local language, know and understand the local culture, know which groups are most vulnerable in a disaster or disaster. ${ }^{40}$ Faithbased organizations also play an essential role in networking after and before a disaster occurs. ${ }^{41}$ Therefore, faith-based organizations have the advantage of interacting with society. Muhammadiyah, for example, in responding to the Covid-19 problem, established the Muhammadiyah Covid-19 Command Center. This institution aims to take prevention and action in response to the Covid-19 pandemic outbreak by encouraging the government to involve all parties to work together and synergize. These institutions are spread throughout Indonesia, one of which is in West Sumatra. ${ }^{42}$

This response is a manifestation of the role of a faith-based organization in the pandemic. According to Shofwan Karim, Chair of Muhammadiyah, if the Covid-19 problem is the problem of the people, Muhammadiyah will also participate in handling the pandemic. ${ }^{43}$ Nahdlatul Ulama, through its representative, Suleman, also has the same view as Muhammadiyah that Covid-

${ }^{35}$ LaporCovid19, 'Sebagian Besar Penyintas Covid19 dan Keluarganya Mendapat Stigma', Siaran Pers, 2020 $<$ https://laporcovid19.org/category/siaranpers/> [accessed 18 November 2020].

36 Kementerian Kesehatan RI, UNICEF, and WHO, 'Survei Penerimaan Vaksin COVID-19 Di Indonesia', November, 2020, 6-7 $<$ https://www.unicef.org/indonesia/id/coronavirus/1 aporan/survei-penerimaan-vaksin-covid-19-diindonesia $>$. WHO.

37 Kementerian Kesehatan RI, UNICEF, and

38 J. C. Gaillard and P. Texier, 'Religions, Natural Hazards, and Disasters: An Introduction', Religion, 40.2 (2010),

<https://doi.org/10.1016/j.religion.2009.12.001>
${ }^{39}$ Matt Gillard and Douglas Paton, 'Disaster Stress Following a Hurricane: The Role of Religious Differences in the Fijian Islands.', Australasian Journal of Disaster and Trauma Studies, 2.January 1999 (1999), 5.

40 Adisaputri.

41 Andreana Reale, 'Acts of $\operatorname{God}(\mathrm{s})$ : The Role of Religion in Disaster Risk Reduction', Humanitarian Practice Network, September 2010 $<$ https://odihpn.org/magazine/acts-of-gods-the-role-

42 MCCC, 'Pembentukan MCCC Tingkat Wilayah' $<$ https://covid19.muhammadiyah.id/tentang-

$\mathrm{kami} /$ jaringan-mccc-wilayah/> [accessed 18 November 2020]. Interview $\{$ Thursday, 15 October 2020$\}$. of-religion-in-disaster-risk-reduction $/>$.

43 Shofwan Karim (Chair of Muhammadiyah), 
19 is a community problem that must be resolved collectively. ${ }^{44}$ The participation of these two organizations is significant in West Sumatra because both of them have a strong relationship with the community. Therefore, this organization is a social capital that can create social resilience against Covid-19 in West Sumatra, especially in the adaptation of the new normal. Because, according to Regnerus, religion can be a way for faith-based organizations to encourage attachment to society so that they want to commit voluntarily. ${ }^{45}$

Suleman also explained that Nahdlatul Ulama of West Sumatra does not have legal cooperation with the local government in helping the community. However, because this is in the interest of the people, there is an urge to help each other. The assistance provided is not only related to humanitarian assistance but also socialization of new normal through Ulama who are members of the organization. ${ }^{46}$ Shofwan added, Ulama can socialize this new norm from small things related to worship. Shofwan gave an example related to ablution (wudhu); this activity aims to purify oneself and at least five times a day by a Muslim. When it comes to today's conditions, this activity of ablution is relevant to the government's recommendation to wash hands diligently. Because, according to Shofwan, ablution is a habit that is inherent in society. Suleman and Shofwan's explanation suggests that the new customary norms can be localized in West Sumatra effectively. ${ }^{47}$
Besides, organizations such as Muhammadiyah and Nahdlatul Ulama are considered necessary in social networks and the dynamics of community structures. These organizations committed to the principles and practices of the community than to state institutions and tend to extend their services and benefits not only to their members but also to non-members. Therefore, faith-based organizations can function as a forum that encourages social capital. There is a moral agenda in faith-based organizations, namely as social capital which is not only a collection of social networks for religious people but also raises moral forces outside themselves that encourage them to be cooperative. ${ }^{48}$ Muhammadiyah and Nahdlatul Ulama as a faith-based organization have the social capital to encourage cooperation from the people of West Sumatra who are Muslim, to be cooperative in preventing the spread and handling of Covid-19. It is seen when Muhammadiyah urged the people of West Sumatra not to perform Friday prayers at the beginning of the spread of the Covid-19 virus in West Sumatra in March. ${ }^{49}$ The appeal conveyed by Muhammadiyah will encourage cooperation from the people of West Sumatra to comply because Muhammadiyah's social capital is a faith-based organization.

The National Ulama Council (Majelis Ulama Indonesia) of West Sumatra, as a religious organization, calls for not carrying out congregational prayers (shalat berjamaah) at mosques. ${ }^{50}$ This appeal was later supported by other faith-based organizations in West

<https://www.cnnindonesia.com/nasional/20200326 164252-20-487196/muhammadiyah-sumbar-imbauwarga-tak-salat-jumat-besok $>$ [accessed 18 November 2020].

50 'MUI, Kemenag, dan PW NU Sumbar Sepakat Soal Imbauan Tidak Salat Jumat Di Mesjid', Sumbar Fokus <https://www.sumbarfokus.com/berita-muikemenag-dan-pw-nu-sumbar-sepakat-soal-imbauantidak-salat-jumat-di-masjid.html $>$ [accessed 18 November 2020]. 
Sumatra such as NU. However, public acceptance regarding the implementation of congregational prayers is based on the trust of the people of West Sumatra in faith-based organizations; this can be realized because of the existence of social capital, and the position of faith-based organizations that are close to local communities because they have the same identity, Islam. Islam is an ethnic identity, between religion and the Minangkabau people is an inseparable unity. These two elements mutually determine a person's membership in the community, which is primarily determined by the attachment of this identity. ${ }^{51}$ In West Sumatra itself, Islamic identity is attached to the Minangkabau ethnicity. ${ }^{52}$ This identity gave birth to closeness to Buya. They are prominent figures for the people of West Sumatra. The faith-based organization in West Sumatra later became a forum for Buya. ${ }^{53}$ Through Buya, health norms related to the new normal can be disseminated in religious lectures. So that education and internalization of these values in everyday life becomes more manageable. Because according to Nishimuko, faith-based organizations can have an educational role because they can provide opportunities and mobilize people to participate. ${ }^{54}$

Islam as a religion has mutually agreed with norms in behaving towards others, which are known as ta'awun, takaful, and tadhamun as social capital in Islam. ${ }^{55}$

51 Kusnadi, Nelayan: Strategi Adaptasi dan Jaringan Sosial (Bandung: Utama Press, 2000), p. 21.

52 M Elfira, "Not Muslim, Not Minangkabau" Interreligious Marriage and Its Cultural Impact in Minangkabau Society', in Muslim-Non-Muslim Marriage: Political and Cultural Contestations in Southeast Asia (Institute of Southeast Asian Studies, 2009), p. 161.

53 Jufri Naldo, 'Islam dan Modal Sosial Orang Minangkabau di Perantauan', Jurnal Penelitian, 13.2 (2019), 267.

${ }^{54}$ Mikako Nishimuko, 'The Role of Faith-Based Organizations in Building Democratic Process: Achieving Universal Primary Education in Sierra Leone', International Journal of Educational and Pedagogical Sciences, 20.4 (2008), 377.
Ta'awun is understood as an activity to help the goodness of fellow Muslims. In ta'awun, it should not be questioned about who is being helped and who is helping and does not see the rank, degree or property of a person. Ta'awun (النعاون) in Islam is to help each other, especially to fellow believers who are united by the same belief in Allah. ${ }^{56}$ Ta'awun (التعاون) can then be understood as one of the social capitals in Islam so that fellow Muslims will have ta'awun norms as their social capital. Takaful (التكافل) is rooted from the word kafl, which means a guarantee or take responsibility. Takaful (التكافل) is defined as 'sharing', sharing in terms of responsibility, assurance. ${ }^{57}$ Takaful (التكافل) can be interpreted as the norm of mutual support. Meanwhile, Tadhamun (التضامن) has an attitude of solidarity between fellow Muslims. ${ }^{58}$

Ta'awun, takaful, and Tadhamun (التعاون are social capital in Islam, following Putnam's argument that faith-based organizations are the estuaries and drivers of social capital. So faith-based organizations can play a role in encouraging cooperation through social capital in Islam. They were mainly driven by the criteria of faith-based organizations that are considered close to local communities. Ta'awun, Takaful, and Tadhamun (التعاون و التكافل) then encourage people to behave to participate in tackling the Covid-19 outbreak with faith-based organizations as the driving force. Besides, by practising these three

55 Atih Rohaeti Dariah, Muhammad Syukri Salleh, and Hakimi M. Shafiai, 'A New Approach for Sustainable Development Goals in Islamic Perspective', Procedia - Social and Behavioral Sciences, 219 (2016), 165 <https://doi.org/10.1016/j.sbspro.2016.05.001>.

56 Nabilah Amalia Balad, 'Prinsip Ta'awun Dalam Konsep Wakaf Dengan Perjanjian Sewa Menyewa Berdasarkan Undang-Undang Nomor 41 Tahun 2004 Tentang Wakaf, Jurnal Hukum Magnum Opus, 2.2 (2019), $18-28$.

57 Brian Kettell, 'Introduction to Islamic Banking and Finance' (UK: Wiley, 2011), pp. 128-29.

58 Hadi Daeng Mapuna, 'Asuransi Jiwa Syariah; Konsep dan Sistem Operasionalnya', Al-Risalah Jurnal Ilmu Syariah dan Hukum, 19.1 (2019), 162 <https://doi.org/10.24252/al-risalah.v19i1.9976>. 
attitudes, the government will be assisted in overcoming the challenges of implementing the new normal in West Sumatra.

\section{Conclusion}

Years have passed; Indonesia is still working to fight the Covid-19 virus. Indonesia has set a standard for controlling the virus, namely 3T, namely testing, tracing, and treatment in all its provinces, including West Sumatra. Besides, West Sumatra has also adopted the new normal. However, the number of positive cases is increasing. Even though West Sumatra has passed a regulation that contains sanctions for those who violated, this is undoubtedly a challenge for the government. To maximize it, we need to synergy from various actors, including faithbased organizations. This organization functions as a forum that encourages social capital, which, in this case, can be in the form of norms or values. Through this organization, religious leaders can play an active role in conveying health values and correct information to the public through lectures. Besides, the emotional closeness between society and this organization makes it easier to convey these values. With values such as ta'awun, takaful, and tadhamun (النعاون و التكافل in Islam, the people of West Sumatra can be invited to prevent the spread of the virus. Challenges such as the character and public perception of Covid-19 can be straightened out through this organization. It is possible because the people of West Sumatra have a strong connection to Ulama, one of the three prominent actors in Minangkabau Culture. A faith-based organization such as Muhammadiyah and Nahdlatul Ulama is an organization where Ulama belong. This connection has become a social capital between them. Therefore, it cannot be denied; this organization can influence local communities and have an essential function as social capital, especially in West Sumatra.

\section{References}

\section{Books}

Brian Kettell, 'Introduction to Islamic Banking and Finance' (UK: Wiley, 2011)

Bush, R., Muhammadiyah and disaster response: Innovation and change in humanitarian assistance. In Natural Disaster Management in the Asia-Pacific, (Tokyo: Springer, 2015)

Clarke, G., M. Jennings, \& T. Shaw, (Eds.), Development, civil society and faith-based organizations: Bridging the sacred and the secular, (New York: Palgrave Macmillan, 2007)

Elfira, M., "Not Muslim, not Minangkabau" Interreligious marriage and its cultural impact in Minangkabau society. In Muslim-Non-Muslim Marriage: Political and Cultural Contestations in Southeast Asia. Institute of Southeast Asian Studies, 2009, p. 161

Kusnadi, Nelayan; Strategi Adaptasi dan Jaringan Sosial, (Bandung: Utama Press, 2000), pp. $50-51$

Putnam, R.D., Bowling Alone: The Collapse and Revival of American Community. (New York: Simon and Schuster, 2000)

\section{Journals}

Baidhawy, Z., The role of faith-based organization in coping with disaster management and mitigation: Muhammadiyah's Experience. Journal of Indonesian Islam, 9(2), 2015, 184

Balad, N. A., Prinsip Ta'awun dalam Konsep Wakaf dengan Perjanjian Sewa Menyewa Berdasarkan Undang-undang Nomor 41 Tahun 2004 Tentang Wakaf, Jurnal Hukum Magnum Opus, 2(1), (2019), 19

Bunn, C., \& M. Wood, Cultured responses: The production of social capital in faith based organizations. Current Sociology, 60(5), 2012, 636

Chikwendu, Eudora, Faith-Based Organizations in Anti-HIV/AIDS Work 
Among African Youth and Women, Dialectical Anthropology, 28(3), 2004, 324

Dariahak, A. R. M. S. Sallehb, and H. M. Shafiai, A New Approach for Sustainable Development Goals in Islamic Perspective. Procedia-social and Behavioral Sciences, 219, 2016, 165

Fitri, R., M.F. Adnan, \& Syamsir, Peranan Kepemimpinan Alim Ulama dalam Meningkatkan Partisipasi Pemilih pada Pilkada di Kota Padang Panjang. Jurnal Ranah Research 1 (2), 2019, 280-285

Fukuyama, Francis, Social Capital and Civil Society, IMF Working Paper, April 2000

Gaillard, Jean-Christophe, \& Pauline Texier, Religions, natural hazards, and disasters: An introduction, Religion, 40 (2), 2010, 83

Gillard, M., \& D. Paton, Disaster Stress Following A Hurricane: The Role of Religious Differences in the Fijian Islands. The Australasian Journal of Disaster and Trauma Studies, 24 (2), 1999, 5

Hepworth, C., \& S. Stitt, Social Capital \& Faith-Based Organisations. The Heythrop Journal, 48(6) (2007), 904

Hilman, Y. A., Disaster Management Concept of Muhammadiyah Disaster Management Centre in Ponorogo, Indonesia. Otoritas: Jurnal Ilmu Pemerintahan, 8(1), 2018, 67

Kementerian Kesehatan, ITAGI, UNICEF, WHO, Survei Penerimaan Vaksin Covid19 di Indonesia, Report, November 2020,

Kettell, B., Introduction to Islamic Banking \& Finance, International Journal of Islamic and Middle Eastern Finance and Management, 1(4), 2008, 128-129

le Roux, Elisabet, Faith-based HIV Response in post-Soviet Eastern Europe: the case of Channels of Hope in Russia, Romania, and Armenia, Development in Practice, 27(5), 2017, 658-669

Mapuna, H. D., Asuransi Jiwa Syariah; Konsep dan Sistem Operasionalnya. Al-Risalah Jurnal Ilmu Syariah dan Hukum, 19(1) 2019,162
Marpuah, Dinamika Muhammadiyah sebagai Gerakan Pembaruan di Provinsi Sumatera Barat. Jurnal PENAMAS 33 (1), 2020, 115

Naldo, J. N., Islam dan Modal Sosial Orang Minangkabau di Perantauan. Jurnal Penelitian, 13(2), 2019, 267

Nishimuko, Mikako, The Role of Faith-based Organizations in Building Democratic Process: Achieving Universal Primary Education in Sierra Leone, International Journal of Educational and Pedagogical Sciences, 2(4), 2008, 377

Regnerus, M.D., Religion and Positive Adolescent Outcomes: A Review of Research and Theory. Review of Religious Research 44(4), 2003, 401

Rohman, F.A., \& Mulyati, Rintisan Pendidikan Awal Muhammadiyah di Sumatra Barat Tahun 1925-1939, Jurnal Penelitian Sejarah dan Budaya 5 (1), 2019, 26

Ross, Allen G.P., Remigio M. Olveda, Li Yuesheng, Are we Ready for a Pandemic of Ebola Virus?, International Journal of Infectious Disease 28(C), 2014, 218

Salim, D.P., \& L. Kryati, Politik Pendidikan Agama dan Perubahan Prilaku Di Sumatera Barat, El-Hekam: Jurnal Studi Keislaman, 2.(1), 2018, .51

Yeary, C. K. K. H., S. Ounpraseuth, P. Moore, Z. Bursac, \& P. Greene, Religion, social capital, and health. Review of Religious Research, 54(3), 2012, 344

Zainal, Gerakan Islamis di Sumatera Barat Pasca Orde Baru, MIQOT 38 (2), 2014, 462

Zulfadli, Anggraini, D., and Fajri, M. From Formalization of Sharia to Islamic Conservatism: The Post Reform of Islamic Movement Phenomena in West Sumatera. Al'Araf Jurnal Pemikiran Islam dan Filsafat 17 (1), 2020, 9-13

\section{Thesis and Dissertation}

Adisaputri, G., The Role of Religious Beliefs and Practices in Disaster: The Case Study of 2009 Earthquake in Padang 
City, Indonesia (Unpublished Doctoral dissertation, Auckland University of Technology, 2016)

\section{Articles in Newspapers and Magazines}

Arriani, A. et al, The Community's Perception of Covid-19, Suara Komunitas 1st Ed, August 2020

Reale, A., Acts of God (s): the role of religion in Disaster Risk Reduction. Humanitarian Exchange Magazine, 48(1), 2010, p.1-2.

\section{Online database}

Shira, Dezan and Associates, The Coronavirus in Asia and ASEAN - Live Updates by Country, ASEAN Briefing, 22 November 2020, $<$ https://www.aseanbriefing.com/new s/coronavirus-asia-asean-live-updatesby-country $/>$, accessed 23 November 2020

Khalisotussurur, Lilis and Andri Mardiansyah, Hari ini Sumbar Resmi Terapkan New Normal, VivaNews, 8 June 2020, $<$ https://www.viva.co.id/berita/nasion al/1278556-hari-ini-sumbar-resmiterapkan-new-normal> accessed 18 November 2020

Burhan, F.A., Pakai Istilah New Normal, Masyarakat Justru Langgar Protokol Covid-19, Katadata, 11 Juli 2020, $<$ https://katadata.co.id/febrinaiskana/ berita/5f099ac589ca7/pakai-istilahnew-normal-masyarakat-justru-langgarprotokol-covid-19>, accessed 8 November 2020

Badan Pusat Statistik Provinsi Sumatera Barat, Provinsi Sumatera Barat dalam Angka 2020. BPS Provinsi Sumatera Barat

Kantor Wilayah Kementerian Agama Provinsi Sumatera Barat, Data Ormas dan Lembaga Keagamaan, 2016, $<$ https://sumbar.kemenag.go.id/v2/po st/50552/data-ormas-dan-lembagakeagamaan $>$, accessed 14 November 2020
Visi dan Misi, Muhammadiyah Disaster Management Center, $<$ https://www.mdmc.or.id/profilmdmc/visi-dan-misi/>, accessed 18 November 2020

NU, AusAID extend aid for quake victims, TheJakartaPost, 31 October 2009, $<$ https://www.thejakartapost.com/new s/2009/10/31/nu-ausaid-extend-aidquake-victims.html.> accessed 18 November 2020

Sekretariat Kabinet RI, Rapat Terbatas mengenai Percepatan Penanganan Pandemi Covid-19, 13 July 2020, $<$ https://setkab.go.id/rapat-terbatasmengenai-percepatan-penangananpandemi-covid-19-13-juli-2020-diistana-merdeka-provinsi-dki-jakarta/>, accessed 18 November 2020

Badan Pusat Statistik, Perilaku Masyarakat Di Masa Pandemi Covid-19, p.17, $<$ https://covid19.go.id/edukasi/hasilkajian/hasil-survei-perilaku-masyarakatdi-masa-pandemi-covid-19>, accessed 18 November 2020

LaporCovid19, Sebagian Besar Penyintas Covid-19 dan Keluarganya Mendapat Stigma, Siaran Pers, 27 August 2020, $<$ https://laporcovid19.org/category/si aranpers/>, accessed 18 November 2020

MCCC, Pembentukan MCCC Tingkat Wilayah, $<$ https://covid19.muhammadiyah.id/te ntang-kami/jaringan-mccc-wilayah/>, accessed 18 November 2020

Muhammadiyah Sumbar Imbau Warga Tak Shalat Jumat Besok, CNN Indonesia, 26 March 2020 , $<$ https://www.cnnindonesia.com/nasi onal/20200326164252-20487196/muhammadiyah-sumbarimbau-warga-tak-salat-jumat-besok>, accessed on 18 November 2020

MUI, Kemenag, dan PW NU Sumbar Sepakat Soal Imbauan Tidak Salat Jumat di Mesjid, Sumbar Fokus, 16 April 2020, $<$ https://www.sumbarfokus.com/berit 
a-mui-kemenag-dan-pw-nu-sumbarsepakat-soal-imbauan-tidak-salat-jumatdi-masjid.html>, accessed 18 November 2020

Sumbar Tanggap Corona, Data Pantauan 3 November 2020 $<$ https://corona.sumbarprov.go.id/det ails/index_master_corona>, accessed 18 November 2020

Peta Sebaran 8 November 2020, $<$ https://covid19.go.id/peta-sebaran>, accessed 8 November 2020

\section{Interviews}

Karim, Shofwan (Chair of Muhammadiyah West Sumatra Region), Interview \{Thursday, 15 October 2020\}

Suleman (Secretary of Nahdlatul Ulama West Sumatra Region), Interview \{Sunday, 5 October 2020\} 